Original Article

\title{
EVALUATION OF IN VITRO ANTICANCER AND ANTIOXIDANT ACTIVITIES FROM LEAF EXTRACTS OF MEDICINAL PLANT CLIDEMIA HIRTA
}

\section{DOKKA NARASIMHAM ${ }^{1,2 *}$, YEDUGURI HIMA BINDU ${ }^{3}$, SANITH CHERIYAMUNDATH ${ }^{1}$, RAHUL RAGHAVAN ${ }^{1}$, MERUVA KEERTHI KUMARI ${ }^{2}$, THUMMALA CHANDRASEKHAR ${ }^{2}$, JOSEPH MADASSERY ${ }^{1}$}

\author{
${ }^{1}$ Department of Biotechnology, University of Calicut, Kerala, India, ${ }^{2}$ Department of Environmental Science, Yogi Vemana University, A. P, \\ India, ${ }^{3}$ Department of Biotechnology and Bioinformatics, Yogi Vemana University, A. P, India \\ Email: simhabt17@gmail.com
}

Received: 05 Dec 2016 Revised and Accepted: 27 Feb 2017

\begin{abstract}
Objective: To evaluate the anticancer and antioxidant activity of medicinal plant Clidemia hirta extracted in different solvents.
\end{abstract}

Methods: Crude extracts were prepared from the leaves of Clidemia hirta using ethanol, petroleum ether and chloroform solvents. Anticancer activities and antioxidant properties were assayed using standard yellow dye 3-(4,5-dimethyl-2-thiazolyl)-2,5-diphenyl- $2 \mathrm{H}$-tetrazolium bromide (MTT) and 1, 1-diphenyl-2-picryl hydrazyl (DPPH) free radical scavenging assay respectively.

Results: We found that the ethanol extract had higher inhibition activities against Dalton's lymphoma ascites (DLA) cancer cell line, 50\% DLA cell line inhibition at $68 \mu \mathrm{g} / \mathrm{ml}$, while $50 \%$ inhibition by petroleum ether and chloroform extracts were at $160 \mu \mathrm{g} / \mathrm{ml}$ and $172 \mu \mathrm{g} / \mathrm{ml}$, respectively. The antioxidant activity requires $5 \mu \mathrm{g} / \mathrm{ml}$ of ethanol extract to trap $50 \%$ of DPPH ( $\mathrm{IC}_{50}$ ), whereas the positive control ascorbic acid trapped $50 \%$ of DPPH $\left(\mathrm{IC}_{50}\right)$ at $3.5 \mu \mathrm{g} / \mathrm{ml}$.

Conclusion: The prepared leaf extracts with different solvents of Clidemia hirta showed the antiproliferative and antioxidant activity in dosedependent manner. Further works is required to identify the biologically active chemical constituents, responsible for cancer cell growth inhibition from this plant.

Keywords: Anticancer, Antioxidant, MTT Assay, DPPH Free Radical

(c) 2017 The Authors. Published by Innovare Academic Sciences Pvt Ltd. This is an open access article under the CC BY license (http://creativecommons.org/licenses/by/4.0/) DOI: http://dx.doi.org/10.22159/ijpps.2017v9i4.16843

\section{INTRODUCTION}

Plants products are being used for the treatment of various diseases almost from the human race began. For many millions of people, often living in rural areas of developing countries, herbal medicines, traditional treatments, and traditional practitioners are the main, sometimes the only, source of health care World Health Organization (WHO) 2015. Cancer is a major public health problem worldwide and is the second-leading cause of death in the United States [1] and there is a necessity to identify new compounds with cytotoxic activity for the treatment of cancer. Presently, there is a considerable scientific discovery for the invention of anticancer agents from natural products [2]. In light of the continuing need for effective anticancer agents and edible plants are increasingly being considered as sources of anticancer drugs [3-4]. In extent, there is a large amount of scientific evidence showing that the fruits and vegetables lower the risk of cancer [5]. Medicinal plants constitute the main source of new pharmaceuticals and healthcare products, including medications for ethnoveterinary medicine [6]. Moreover, phytochemical examination has been making rapid progress, and herbal products are becoming popular as sources of plausible anticancer compounds [7]. Several drugs currently used in chemotherapy were isolated from plant species or derived from a natural prototype. They include the Vinca alkaloids, vinblastine and vincristine [8], isolated from Catharanthus roseus, etoposide and teniposide, the semisynthetic derivatives of epipodophyllotoxin, isolated from species of the genus Podophyllum [9-10], the naturally derived taxanes isolated from species of the genus Taxus, the semisynthetic derivatives of camptothecin, irinotecan and topotecan, isolated from Camptotheca acuminata, and several others [11-13].

Normally cells have defense system to eliminate the reactive oxygen species (ROS) include a variety of free radicals such as superoxide anion $\left(\mathrm{O2}^{\circ}-\right)$, hydroxyl radical $\left(\mathrm{OH}^{\circ}\right)$, nitric oxide radical ( $\left.\mathrm{NO}^{\circ}\right)$, and peroxyl radical $\left(\mathrm{RO}_{2}{ }^{-}\right)$, and non-free radical species such as hydrogen peroxide $\left(\mathrm{H}_{2} \mathrm{O}_{2}\right)$ [14]. But when these free radicals go out of control, the cell fails to eliminate these ROS which may lead to the development of chronic diseases, such as cancer, arteriosclerosis, nephritis, diabetes mellitus, liver injury, rheumatism, ischemia, cardiovascular and neurodegenerative disorders such as Alzheimer's and Parkinson's disease [15]. Studies showed that certain plants contain a large variety of substances that possess antioxidant activity [16]. Phytochemicals with antioxidant effects include some cinnamic acids, coumarins, diterpenes, flavonoids, lignans, monoterpenes, phenylpropanoids, tannins and triterpenes [17-18]. It has been well documented that, in addition to endogenous antioxidant defence system, an external supply of both synthetics as well plant derived natural antioxidants appears to play a significant role in oxidative stress imbalances [19-20].

Clidemia hirta also known as (soapbush or) Koster's curse, belongs to the family of Melastomataceae which is the seventh-largest family of flowering plants. It is an occasional plant in the environment with high rainfalls and interestingly growth, flowering and fruiting have been observed throughout the year. The plant is native to West Indies and Central America. Although there are few reports on antibacterial activity [21] of this plant but there is no report available on anti-cancer activity till date. Therefore, in the present study, we focused on anticancer activity including the antioxidant activity of leaf extract of Clidemia hirta. The anti-cancer activity of leaf extract was assessed by looking into cell viability, inhibitory concentration and observing cell morphological changes after treatment with leaf extract. The antioxidant activity was evaluated through DPPH method.

\section{MATERIALS AND METHODS}

\section{Collection of plant material}

The leaves of Clidemia hirta were provided by Dr. M. Sabu, professor, department of botany, from the botanical garden, University of Calicut, Kerala, India. 


\section{Preparation of crude extraction}

The fresh leaves of Clidemia hirta were washed under the running tap water, shade-dried for $5 \mathrm{~d}$ and oven-dry at $55^{\circ} \mathrm{C}$ for $24 \mathrm{hrs}$. The sample was ground to a fine powder using an electrical mixer. The leaf powder (5 gm) was suspended in $40 \mathrm{ml}$ of ethanol, petroleum ether or chloroform and kept on a rotatory shaker for continuous agitating for $24 \mathrm{hrs} *$. The extracts were filtered using whatman no. 1 filter paper, and the filtrates were dried at ambient temperature in a fume hood in the dark until all solvent evaporated.

\section{Cell culture maintenance}

The cell line used for the anticancer activity was DLA cancer cell line, obtained from the department of biotechnology, Calicut University, Kerala, India. The cells were grown and maintained in RPMI-1640 (HI Media) media, supplemented with $10 \% \mathrm{v} / \mathrm{v}$ fetal bovine serum, sodium carbonate and also $100 \mathrm{mg} / \mathrm{l}$ penicillin, $50 \mathrm{mg} / \mathrm{l}$ streptomycin to prevent the bacterial contamination and incubated at $37^{\circ} \mathrm{C}$ in a humidified atmosphere of $5 \% \mathrm{CO}_{2}$.

\section{Cell viability and proliferation assay (MTT)}

The cytotoxic activity of plant extract against DLA cells was determined by MTT assy. MTT assay was performed in a 96-well culture plate according to a previously published protocol [22]. The plant extract was dissolved in dimethyl sulfoxide (DMSO) and diluted appropriately by using RPMI medium. Then $10^{5} \mathrm{cells} / \mathrm{ml}$ were seeded into each well of a microtiter plate then plant extracts were added at concentrations $20,40,60$ and $200 \mu \mathrm{g} / \mathrm{ml}$ per well. The volume in each well was made up to $200 \mu \mathrm{l}$ with RPMI medium. Cells treated with DMSO were used as a control. The treated cells were incubated in $\mathrm{CO}_{2}$ incubator for $48 \mathrm{hrs} *, 20 \mu \mathrm{l}$ of MTT (HI Media) solution $(5 \mathrm{mg} / \mathrm{ml})$ was added into each well and incubated for 4 hrs*. Purple-colored formazan crystals formed in each well were dissolved by adding $200 \mu \mathrm{l}$ of DMSO. The optical density was measured at $570 \mathrm{~nm}$. All the experiments were performed in triplicates. Percentage of viability was checked by calculated stimulation index using following formulae.

$$
\begin{gathered}
\text { Stimulation index }=\frac{\text { Absorbance with plant extract }}{\text { Absorbance without plant extract }} \\
\% \text { of viability }=\text { stimulation index } \times 100
\end{gathered}
$$

\section{Free radical scavenging activity by DPPH method}

Free radical scavenging activity assay was performed according to previously published procedures [23-25]. DPPH (HI Media) solution was prepared by dissolving $25 \mathrm{mg}$ in $1 \mathrm{~L} 80 \%$ methanol. Then $1 \mathrm{ml}$ of DPPH solution was added to each test tube in two series followed by the addition of $1 \mu \mathrm{g} / \mathrm{ml}, 2 \mu \mathrm{g} / \mathrm{ml}, 3 \mu \mathrm{g} / \mathrm{ml}$ up to $10 \mu \mathrm{g} / \mathrm{ml}$ of test sample to one series and $1 \mu \mathrm{g} / \mathrm{ml}, 2 \mu \mathrm{g} / \mathrm{ml}, 3 \mu \mathrm{g} / \mathrm{ml}$ up to $10 \mu \mathrm{g} / \mathrm{ml}$ of ascorbic acid to another series. Mixtures were shaken well and kept in the dark at $37^{\circ} \mathrm{C}$ for $60 \mathrm{~min} .100 \%$ methanol was taken as blank, DPPH as a negative control and ascorbic acid as a positive control and the absorbance was measured at $517 \mathrm{~nm}$. All the experiments were performed in triplicate and the percentage of inhibition was calculated by the following equation.
$\%$ anti-free radical activity $=$

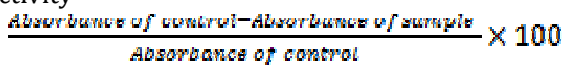

\section{Statistical analysis}

In the present study, all the experiments were conducted in triplicate, and data analysis was done by mean \pm SEM.

\section{RESULTS}

\section{Cell proliferation assay (MTT)}

The percentage of cell viability and cytotoxic activity of leaf extracts of Clidemia hirta against DLA cancer cell line was clearly evaluated with MTT assay and microscopic images (fig. 1). Just about $10^{5}$ cells $/ \mathrm{ml}$ were seeded to each well and allowed to incubate overnight. The cells were treated with varying concentrations of different leaf extracts of Clidemia hirta from $20 \mu \mathrm{g} / \mathrm{ml}$ to $200 \mu \mathrm{g} / \mathrm{ml}$. the ethanol extract reduced cell viability in a dose-dependent manner (fig. 2), as compared to the DMSO treated cells. The concentrations of DMSO between 0.0 and $2.0 \%$ did not show any significant effects on the proliferation of DLA cell line (fig. 3) the ethanol extract was most active in this assay, exhibiting lower $\mathrm{IC}_{50}$ values $68 \mu \mathrm{g} / \mathrm{ml}$, where petroleum ether extract $-160 \mu \mathrm{g} / \mathrm{ml}$ and chloroform extract- $172 \mu \mathrm{g} / \mathrm{ml}$ (fig. 4).

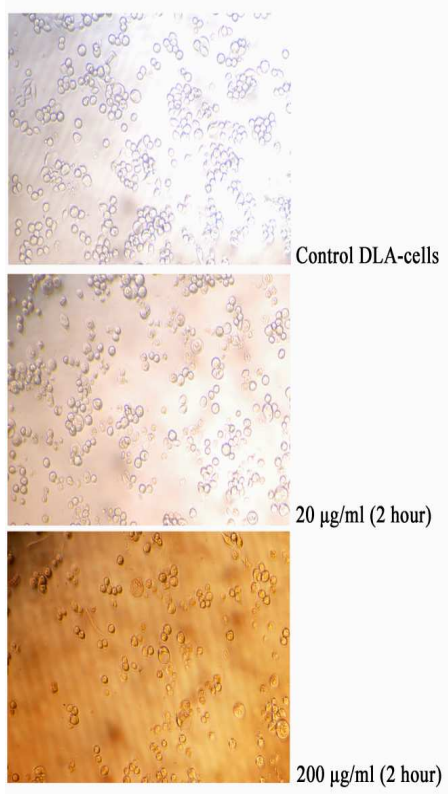

Fig. 1: Effect of ethanol extract against Dalton's lymphoma ascites (DLA) cell line. A. Control DLA cells without treatment, B. Treated cells with $20 \mu \mathrm{g} / \mathrm{ml}$ concentration after $2 \mathrm{~h}, \mathrm{C}$. Treated cells with $200 \mu \mathrm{g} / \mathrm{ml}$ concentration after $2 \mathrm{~h}$

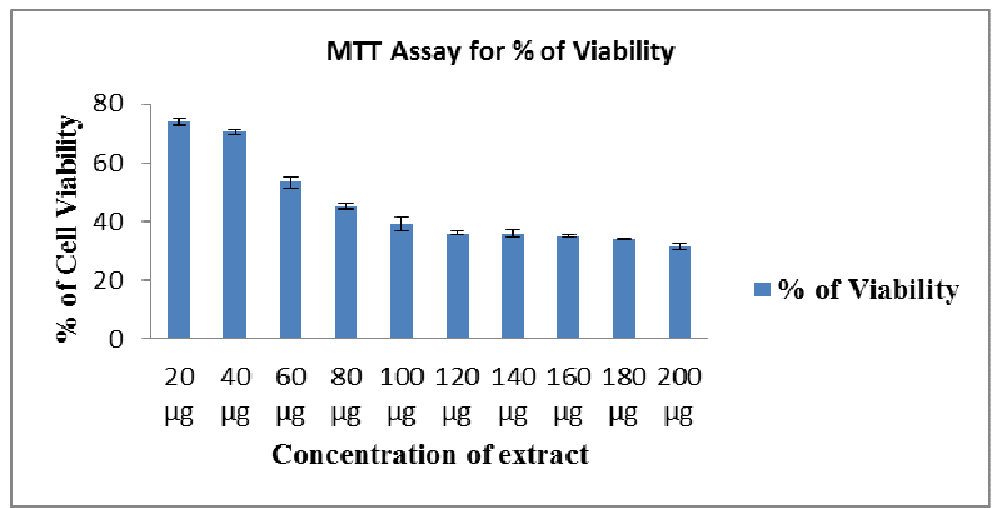

Fig. 2: Percentage viability vs test concentration plot for ethanolic extract of Clidemia hirta showed IC 50 at $68 \mu \mathrm{g} / \mathrm{ml}$. (n=3) 


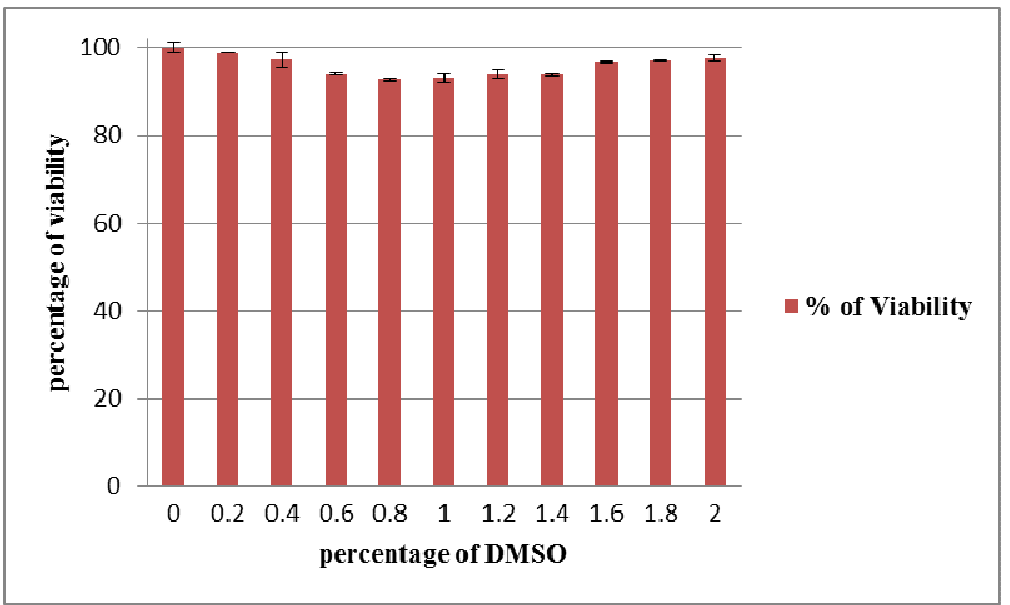

Fig. 3: Percentage viability vs dimethyl sulfoxide (DMSO) concentration plot. DMSO showed no significant effect on Cell viability. (n=3)

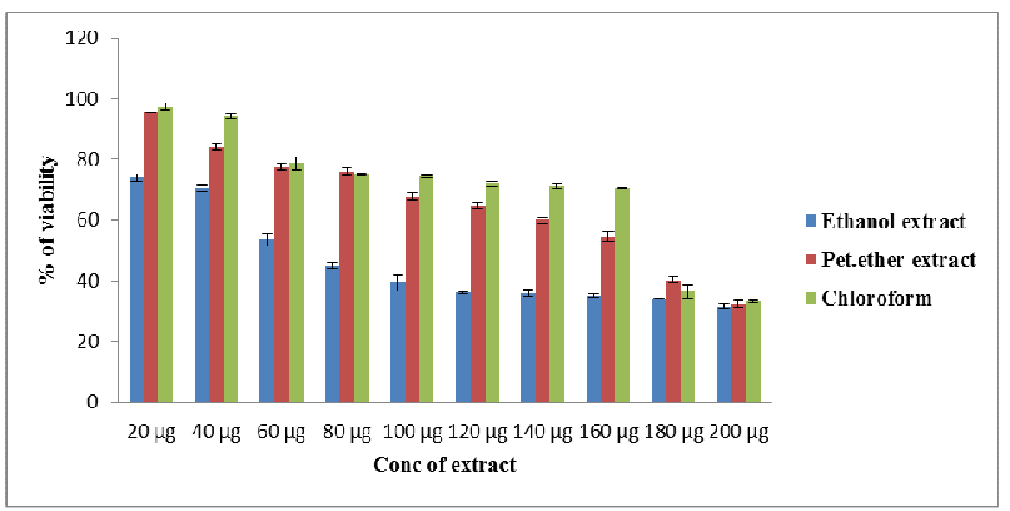

Fig. 4: Percentage viability vs test concentration plot for ethanolic extract, pet. ether and chloroform extracts of Clidemia hirta. (n=3)

In extent we conducted the TLC analysis of ethanol extract of Clidemia hirta was analyzed by preparative TLC with the suitable mobile solvent system and each band was scraped and collected separately. Later we performed MTT Assay to check out the anticancer activity of individual bands. The marked band (fig. 5) was showing anticancer activity while remaining were not having the activity.

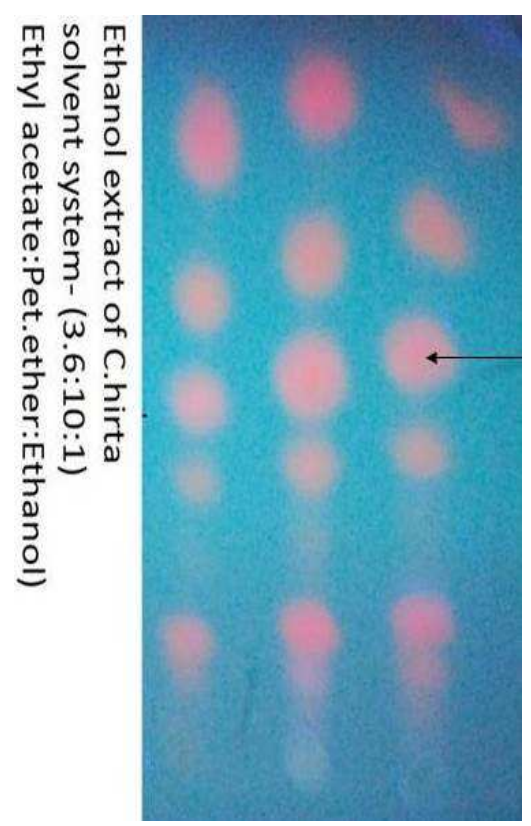

Fig. 5: TLC Analysis of ethanol extract of Clidemia hirta with suitable mobile solvent system and marked band showed the anticancer activity 


\section{Antioxidant assay by DPPH method}

The ethanol extract of Clidemia hirta showed significant antioxidant activity. Free radical scavenging potential was evaluated against DPPH free radical. The ethanol extract of Clidemia hirta has concentration dependent scavenging activity against DPPH free radicals. Antioxidant activity was expressed as
IC $_{50}$, which was defined as the concentration of antioxidant desirable to trap $50 \%$ of DPPH. The $\mathrm{IC}_{50}$ of the Clidemia hirta extract was $5 \mu \mathrm{g} / \mathrm{ml}$ where the ascorbic acid, a well-known antioxidant was $3.7 \mu \mathrm{g} / \mathrm{ml}$. It was clearly observed that absorbance of the test sample and the standard drug was increased with increasing concentration of test and standard. It shows significant reduction capabilities of the test sample (fig. 6).

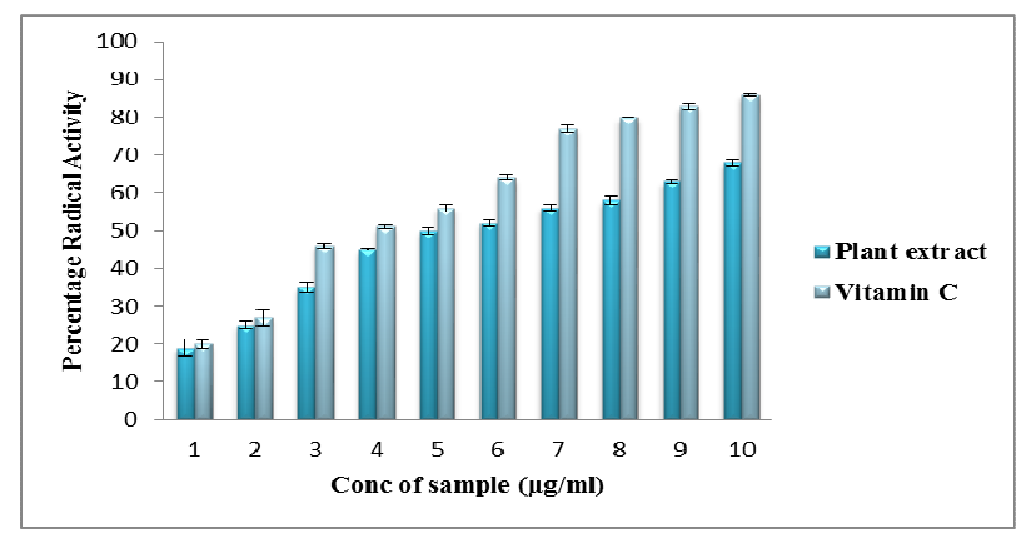

Fig. 6: Percentage radical activity vs test concentration plot for ethanol extract of Clidemia. hirta and standard drug ascorbic acid by DPPH assay. $(n=3)$

\section{DISCUSSION}

Natural products from plants plying as promising candidates in the treatment of cancer diseases and in scavenging free radicles. There has been a continuous search for the development of novel and costeffective drugs from natural sources. The earlier experimental investigations demonstrated that many naturally occurring agents and plant extracts had shown antioxidant and anticancer potential in a variety of bioassay systems and animal models, having relevance to human disease [26]. Moreover, the epidemiological studies suggested that antioxidant supplements might reduce the risk of breast cancer recurrence or breast cancer-related mortality [21]. Previous studies on Clidemia hirta plants used to treat diarrhea, topical irritation and bacterial infection [27-28]. Juice of leaves is applied as cicatrizing, and tea of leaves or mixed tea of leaves and roots are drunk for stomach complaints and heartburn [27]. Only two studies focused on the real antibacterial activity of Clidemia hirta extracts using disk diffusion method $[27,29]$. Though there are reports available on the anti-bacterial activity of Clidemia hirta, but there is no report on in vitro anticancer activity against cell lines. Hence the goal of this work was to develop a potential anticancer and antioxidant compounds from the crude extracts of Clidemia hirta. The present study confirmed that the ethanol leaf extract has a strong dose-dependent anticancer activity against DLA cancer cells with the $\mathrm{IC}_{50}$ at $68 \mu \mathrm{g} / \mathrm{ml}$ when compared to petroleum ether and chloroform leaf extracts and the ethanol leaf extract showed the free radical scavenging activity with $\mathrm{IC}_{50}$ at $5 \mu \mathrm{g} / \mathrm{ml}$ by scavenging the DPPH free radicals.

\section{CONCLUSION}

The ethanol extract of Clidemia hirta showed effective antiproliferative activity against DLA cancer cells with the $\mathrm{IC}_{50}$ at $68 \mu \mathrm{g} / \mathrm{ml}$. Analysis of plant extract was done by TLC; the active compound responsible for the anti-proliferative activity was isolated and purified. Further work needs to be carried out to identify the metabolite and elucidate the mechanism of action.

\section{ACKNOWLEDGEMENT}

The authors are thankful to DBT, New Delhi, India for financial support. Dr. M. Sabu for providing leaf material.

\section{CONFLICT OF INTERESTS}

There is no conflict of interest

\section{REFERENCES}

1. Rebecca LS, Kimberly DM, Ahmedin J. Cancer statistics. Cancer J Clin 2016;66:7-30.

2. Kasahara S, Hemini S. Medicinal Herb Index in Indonesia, Bogor, Indonesia, P. T. Eisai Indonesia; 1998. p. 1-2.

3. Ferguson PJ, Kurowska E, Freeman DJ, Chambers AF, Koropatnick DJ. A flavonoid fraction from cranberry extract inhibits proliferation of human tumor cell lines. J Nutr 2004;134:1529-35.

4. Jo EH, Hong HD, Ahn NC, Jung JW, Yang SR, Park JS, et al. Modulations of the Bcl-2/Bax family were involved in the chemopreventive effects of licorice root (Glycyrrhizauralensis Fisch) in MCF-7 human breast cancer cell. J Agric Food Chem 2004;52:1715-9.

5. Chen MS, Chen D, Dou QP. Inhibition of proteasome activity by various fruits and vegetables is associated with cancer cell death. In Vivo 2004;18:73-80.

6. Ivanova D, Gerova D, Chervenkov T, Yankov T. Polyphenols and antioxidant capacity of Bulgarian medicinal plants. J Ethnopharmacol 2005;96:145-50.

7. Devakumar DJ, Keerthana V, Sudha SS. Identification of bioactive compounds by gc-ms analysis of syzygium jambos (l) collected from western ghats region coimbatore, tamil nadu. Asian J Pharma Clin Res 2017;10:364-9.

8. Roger JP, Leslie NS, Roy E, Beverly L, Joel G, Stacy NH, et al. Outcome for children with medulloblastoma treated with radiation and cisplatin, $\mathrm{CCNU}$, and vincristine chemotherapy. J Neurosurg 1994;81:690-8.

9. Nadeem M, PalniL MS, Purohit AN, Pandey H, Nandi SK. Propagation and conservation of Podophyllum hexandrum Royle: an important medicinal herb. Biol Conserv 2000;92:121-9.

10. Archana G, Lakshmi NM. Production of podophyllotoxin from Podophyllum hexandrum: a potential natural product for clinically useful anticancer drugs. Cytotechnology 2000;34:17-26.

11. Cragg GM, Schepartz SA, Suffness M, Grever MR. The taxol supply crisis. New NCI policies for handling the large-scale production of novel natural product anticancer and anti-HIV agents. J Nat Prod 1993;56:1657-8.

12. Cragg GM, Boyd MR, Cardellina JH, Newman DJ, Snader KM, Mc Cloud TG. Ethnobotany and drug discovery: the experience of the US National Cancer Institute. In: Ethnobotany and the search for new drugs. Wiley, Chichester (Ciba Found Symp 185); 1994. p. 178-96. 
13. Wang HK. Plant-derived anticancer agents currently in clinical use or clinical trials. Investigation Drugs J 1998;1:92-102.

14. Bansal AK, Bilaspuri GS. Impacts of oxidative stress and antioxidants on semen functions. Vet Med Int 2010. Doi:10.4061/2011/686137.

15. Amel OH, Malek BH, Hichem BJ, Ali L, Mahjoub A, Boulbaba S. Antioxidant and antiacetylcholinesterase activities of extracts from Rapistrum rugosum in Tunisia. Asian Pac J Trop Dis 2013;3:367-74.

16. Luciana LM, Fa'bio SM, Gilda GL, Alexandre SR, Tereza dos Santos C, Cintia SC, et al. Screening of brazilian plant extracts for antioxidant activity by the use of DPPH free radical method. Phytother Res 2001;15:127-30.

17. Stocker R. Dietary and pharmacological antioxidants in atherosclerosis. Curr Opin Lipidol 1999;10:589-97.

18. Lingnert $\mathrm{H}$, Vallentin $\mathrm{K}, \mathrm{E}$ Eriksson $\mathrm{C}$. Measurement of antioxidative effect in the model system. J Food Process Preserv 1979;3:87-103.

19. Ames BN, Shigenaga MK, Hagen TM. Oxidants, antioxidants, and the degenerative diseases of aging. Proc Natl Acad Sci U S A 1993;90:7915-22.

20. Halliwell B. Oxygen and nitrogen are pro-carcinogens. Damage to DNA by reactive oxygen, chlorine and nitrogen species: measurement, mechanism and the effects of nutrition. Mutat Res 1999;443:37-52.

21. Dianita R, Ramasamy K, Abrahman N. Antibacterial activity of different extracts of Clidemia hirta (L.) D. Don leaves. Planta Med 2011;77:11.

22. Mosmann T. Rapid colorimetric assay for cellular growth and survival: application to proliferation and cytotoxicity assays. J Immunol Methods 1983;65:55-63.
23. Kumar RS, Sivakumar T, Sunderam RS, Gupta M, Mazumdar UK. Antioxidant and antimicrobial activities of $B$. racemosa $\mathrm{L}$. Brazilian J Med Biol Res 2005;38:1015-24.

24. Mondal SK, Muzumder UK. In vitro antioxidant activity of Diospyros malabarica Kostel bark. Indian J Exp Biol 2006; 44:39-44

25. Ilavarasan R, Mallika M, Venkataraman S. Antiinflammatory and free radical scavenging activity of Ricinus communis root extract. J Ethnopharmacol 2005;103:478-80.

26. Atiqah A, Halimhilmi ZM, Amirin S, Sabariah I. Antioxidant properties of gynura procumbens extracts and their inhibitory effects on two major human recombinant cytochrome p450s using a high-throughput luminescence assay. Asian J Pharma Clin Res 2014;7:36-41.

27. Fleischauer AT, Simonsen N, Arab L. Antioxidant supplements and risk of breast cancer recurrence and breast cancer-related mortality among postmenopausal women. Nutr Cancer 2003;46:15-22.

28. McClatchey W. The ethnopharmacopoeia of Rotuma. J Ethnopharmacol 1996;50:147-56.

29. Meléndez PA, Capriles VA. Antibacterial properties of tropical plants from Puerto Rico. Phytomedicine 2006;13:272-6.

\section{How to cite this article}

- Dokka Narasimham, Yeduguri Hima Bindu, Sanith Cheriyamundath, Rahul Raghavan, Meruva Keerthi Kumari, Thummala Chandrasekhar, Joseph Madassery. Evaluation of in vitro anticancer and antioxidant activities from leaf extracts of medicinal plant Clidemia hirta. Int J Pharm Pharm Sci 2017; 9(4):149-153. 